\title{
Correction to: The emotional dimensions of reason-giving in deliberative forums
}

\author{
Rousiley C. M. Maia ${ }^{1}$ - Gabriella Hauber ${ }^{1}$ \\ Published online: 18 February 2020 \\ ○ Springer Science+Business Media, LLC, part of Springer Nature 2020
}

\section{Correction to: Policy Sciences https://doi.org/10.1007/s11077-019-09363-1}

In the original publication of the article, the second author's name was misspelt. The correct name is given in this Correction.

The original article has been corrected.

Publisher's Note Springer Nature remains neutral with regard to jurisdictional claims in published maps and institutional affiliations.

The original article can be found online at https://doi.org/10.1007/s11077-019-09363-1.

Rousiley C. M. Maia

rousiley@fafich.ufmg.br; rousiley@gmail.com

Gabriella Hauber

gabihauber@gmail.com

1 Department of Communication, Faculty of Philosophy and Social Sciences, The Federal

University of de Minas Gerais, Av. Antônio Carlos, 6.627, Belo Horizonte, MG CEP 31270-901,

Brazil 